\title{
Caregiving Resources and Psychosocial Stimulation Among Infants in Magelang Regency
}

\author{
Diah Yunitawati ${ }^{1, *}$, Leny Latifah $^{1}$ \\ ${ }^{1}$ Health Research and Development Center Magelang, Magelang, Indonesia \\ *Corresponding author. Email: itadiah@yahoo.com
}

\begin{abstract}
The home environment is the main media for child development. Researchs have proven that responsive care plays an important role in child's development. Stimulation and family care become an important factor in child's development. Objective: The objective of this paper is to identify the role of caregiving resources related to psychosocial stimulation of children in Magelang Regency, Central Java. Methods: A cross sectional study was conducted in 4 districts in Magelang Regency which represent replete and non replete iodine deficiency areas. Data were collected from 244 households based on simple random sampling method and data relating 216 samples of mothers and infants were analyzed. The psychosocial stimulation variable was measured using the Home Observation Measurement of the Environment inventory. Mother and infant characteristics were obtained using questionnaires and interviews. Data were analyzed using bivariate analyze and multivariate logistic regression analysis. Results: Most children (more than 50\%) received good psychosocial stimulation. Nearly $2 / 3$ of children aged less than or equal to 6 months and most of them were the first or second child. The age of the mother is mostly in the age of safe reproduction. Psychological status of the mother by $27.78 \%$ felt depressed (moderately depressed) and $37.5 \%$ felt anxious (moderately or severely anxious). The results of the bivariate analysis showed that there was no statistical relationship between the characteristics of mother and child with psychosocial stimulation. Multivariate analysis showed that maternal characteristics were not statistically significantly related, but maternal education and birth order had a risk of given psychosocial stimulation (OR 1.69, CI 0.932-3.066 and OR 2.03, CI 0.906-4.558). Conclusion: Mother's education and birth order may contribute to the psychosocial stimulation provided to children. Recommendation: The risk for low quality of care stimulation is related to formal maternal education, so programs that informally enhanced the quality of stimulation among low-educated mothers need to be strengthened. The significant prevalence of psychological problems in mothers needs to be followed up by looking at their effects on the child's growth and development outcomes.
\end{abstract}

Keywords: caregiving resource, iodine deficiency, psychosocial stimulation

\section{INTRODUCTION}

The situation of children under the age of five living in developing countries has risks related to poverty, malnutrition, poor health, and sub-optimal care environment which will ultimately affect children's cognitive, motoric and social-emotional development. This condition makes the child failed in achieving optimal growth and development potential [1]. Disruption due to iodine deficiency is also one of the risk factors for failure of child development, in addition to a lack of cognitive stimulation and anemia problems [2].

The home environment is the main media for children. Numerous studies have proven that responsive and responsible care plays an important role in children's development. Of the various influential factors, care and interaction within the family are identified as one of the most important factors [3]. Family stimulation is closely related to a child's cognitive development [4]. The situation in the family will directly or indirectly shape the quality of interaction between mother and child. A bad relationship between mother and father will also lead to a bad relationship between mother and child, which can be seen from communication patterns, emotional ties, and variations in stimulation received by children. The mother factor is an important figure that will shape the child's language mastery [5].

Care is a process that involves continuous interaction between children and parents to ensure the health and survival of children, prepare children to become independent adults, be able to interact socially well and behave positively in an impersonal manner [6,7]. Parenting practices and behaviors are one aspect that can influence a child's growth and development. UNICEF's theoretical framework, The Extended Model of Care states that parenting behavior is a mediator between the 
characteristics of caregivers, social factors, health with the growth, development, and survival of children [8].

Childhood becomes an important period in the process of forming the child's personality and determining the progress of his development in the future. The psychological atmosphere in the family and family character will play a role in the process. Parent and child relationships, type of care, and the role of parents will have a significant impact on children's emotions and wellbeing [9]. Parenting style reflects how parents provide discipline and socialization to children. Difficulties in childhood are usually the result of maladaptive family functions, for example, the problem of abuse, both physically, sexually, emotionally. These effects can have an impact in the long run [10].

Children who live in iodine-deficient areas are at risk of intellectual capacity constraints. This condition is not only caused by iodine deficiency but also because of limited access and infrastructure, including health and education issues [11]. Lack of stimulation from parents and low levels of parental education can affect the occurrence of intellectual barriers experienced by children, especially the level of education of mothers who are stronger predictors than the level of education of fathers $[12,13]$. Research conducted in developing countries shows that only a few parents provide cognitive stimulation for their children [14]. Looking at the importance of caring resources for stimulation given to children in environments that are at risk of nutritional problems such as areas with a history of iodine deficiency, this article aims to identify care resources for the psychosocial stimulation of children in Magelang District.

\section{METHOD}

The study was an observational study with a crosssectional method. The study sites were four sub-districts in the Magelang Regency, namely the Districts of Sawangan, Bandongan, Mungkid, and Borobudur. Data was taken in March-December 2016. The selection of this location is based on the results of sampling qualifications as replete and non-replete areas of IDD in Magelang District. Replete areas are represented by Sawangan and Bandongan Districts. Non-replete areas are represented by Mungkid and Borobudur Districts.

The population in this study were mothers and babies who were in the study site as many as 244 mothers and 244 babies were born. The research sample is mothers who complete all research procedures with their babies. Samples were selected by simple random sampling method. The inclusion criterion is willing to be a research respondent and children born alive. Exclusion criteria were the mother did not complete the complete research procedure, the mother and or child suffering from severe illness, or the child died, so they could not follow and complete the research procedure. Samples that met the criteria were 216 people.
This research is part of a research entitled "Growth and Development of Children in Replete and Non Replete Areas of IDD in Magelang Regency" which was published in the 2019 Asian Congress of Nutrition by discussing the topic of iodine in breast milk and child development in replete and non-replete areas, while this article focuses more on the problem of psychosocial stimulation [15].

The variables measured in this study include the demographic characteristics of the mother, the quality of psychosocial stimulation, the level of maternal anxiety and depression, and the characteristics of the child. Demographic characteristics including education and occupation of parents were measured using structured interviews that were asked to mothers. Children's characteristics were measured using a questionnaire that was asked to the mother. The quality of psychosocial stimulation was measured using the HOME Inventory Short Form (HOME-SF) model consisting of 20 items. Data obtained using interviews and direct observation of the interaction between mother and child. Psychosocial stimulation or the quality of the caregiving environment refers to the extent to which the environment provides physical stimulation through sensory input, and emotional stimulation provided through the bond of affection between caregivers and children. The HOME-SF scale has two answer choices, yes (score 1) and no (score 0). Measurement of psychosocial stimulation is done by adding up the scores contained in the HOME-SF questionnaire.

Maternal anxiety levels were measured using the Beck Anxiety Inventory and depression levels were measured by the Beck Depression Inventory. Data obtained by interviews by trained staff and then classified. The characteristics of the child being measured are the order of the child and gender. Data analysis was performed with descriptive analysis, bivariate analysis using the ChiSquare test and logistic regression to determine predictors of childcare practice.

\section{RESULTS AND DISCUSSION}

The samples analyzed in this study were 216 mother and child pairs. Table 1 presents the frequency distribution according to the characteristics of the mother and child who were the subjects of the study. Mother's age is more in the safe age range for reproduction, which is between 21-35 years by 76.4 percent. The youngest age is 16 years and the oldest age is 44 years. 
The analysis showed that mothers with primary education (elementary school and junior high school) were more likely than mothers with higher education. As many as 97.2 percent of mothers breastfeed their babies when data collection is done. The percentage of normal and abnormal maternal nutritional status is almost the same. Most of the mothers have jobs as housewives, which is 77.8 percent. Psychological problems turned out to be pretty much experienced by mothers. Nearly a third of mothers who were the subjects of the study experienced anxiety problems, while the percentage of mothers who experienced depression was 27.8 percent. Characteristics of children are seen by age, sex and birth order. As many as 69 percent of children are less than six months old. The percentage of boys and girls who were the subjects in this study was almost the same. When viewed in order of birth, more subjects became the first child or second child (81 percent).

Table 2. Psychosocial Stimulation

\begin{tabular}{|c|c|c|c|}
\hline $\begin{array}{l}\text { Psychosocial } \\
\text { Stimulation }\end{array}$ & Amount (\%) & Range & Mean (SD) \\
\hline High & $54(25,0)$ & $14-18$ & $8,33(1,23)$ \\
\hline Moderately High & $91(42,1)$ & $12-13$ & $\begin{array}{l}10,48 \\
(0,50)\end{array}$ \\
\hline Medium & $56(25,9)$ & $10-11$ & $\begin{array}{l}12,47 \\
(0,50)\end{array}$ \\
\hline Poor & $15(6,9)$ & $5-9$ & $\begin{array}{l}14,59 \\
(0,84)\end{array}$ \\
\hline Total & $216(100,0)$ & $5-18$ & $\begin{array}{l}12,19 \\
(1,93)\end{array}$ \\
\hline
\end{tabular}

Table 2 shows the psychosocial stimulation carried out by parents in Magelang Regency Of the total 216 subjects, 42.1 percent showed high stimulation and only 6.9 percent had poor stimulation

Table 3. Bivariate Analysis between Mother Characteristics and Child Characteristics with Psychosocial Stimulation

\begin{tabular}{|c|c|c|c|c|c|c|c|}
\hline \multirow{3}{*}{ Variable } & \multicolumn{4}{|c|}{$\begin{array}{l}\text { Psychosocial } \\
\text { stimulation }\end{array}$} & \multicolumn{2}{|c|}{ Total } & \multirow{3}{*}{$\mathrm{p}$} \\
\hline & \multicolumn{2}{|c|}{ Low } & \multicolumn{2}{|c|}{ High } & & & \\
\hline & $\mathbf{N}$ & $\%$ & $\mathbf{N}$ & $\%$ & $\mathrm{~N}$ & $\%$ & \\
\hline Mother's Age & & & & & & & 0,346 \\
\hline$<21$ and $>35$ years & 14 & 27,5 & 37 & 72,5 & 51 & 23,7 & \\
\hline 21-35 years & 57 & 34,5 & 108 & 65,5 & 165 & 76,4 & \\
\hline Breastfeeding Status & & & & & & & 0,980 \\
\hline No & 2 & 33,3 & 4 & 66,7 & 6 & 2,8 & \\
\hline Yes & 69 & 32,9 & 141 & 67,1 & 120 & 97,2 & \\
\hline Education & & & & & & & 0,101 \\
\hline Elementary - junior high school & 47 & 37,3 & 79 & 62,7 & 126 & 58,3 & \\
\hline High school - and above & 24 & 26,7 & 66 & 73,3 & 90 & 41,7 & \\
\hline Maternal nutritional status/IMT & & & & & & & 0,306 \\
\hline$<18,5$ and $>22,9$ & 41 & 36,0 & 73 & 64,0 & 114 & 52,8 & \\
\hline $18,5-22,9$ & 30 & 29,4 & 72 & 70,6 & 102 & 47,2 & \\
\hline Mother's job & & & & & & & 0,188 \\
\hline Does not work & 59 & 35,1 & 109 & 64,9 & 168 & 77,8 & \\
\hline
\end{tabular}




\begin{tabular}{ccccccc}
12 & 25,0 & 36 & 75,0 & 48 & 22,2 & \\
& & & & & & 0,681 \\
28 & 34,6 & 53 & 65,4 & 81 & 37,5 & \\
43 & 31,9 & 92 & 68,1 & 135 & 62,5 & \\
& & & & & & 0,289 \\
23 & 38,3 & 37 & 61,7 & 60 & 27,8 & \\
48 & 30,8 & 108 & 69,2 & 156 & 72,2 & \\
& & & & & & 0,208 \\
53 & 35,6 & 96 & 64,4 & 149 & 69,0 & \\
18 & 26,9 & 49 & 73,1 & 67 & 31,0 & \\
& & & & & & 0,599 \\
36 & 34,2 & 68 & 65,4 & 104 & 48,1 & \\
35 & 31,2 & 77 & 68,8 & 112 & 51,9 & \\
& & & & & & 0,098 \\
62 & 35,4 & 113 & 64,6 & 175 & 81,0 & \\
9 & 22,0 & 32 & 78,0 & 41 & 19,0 & \\
& & & & & & 0,267 \\
39 & 36,4 & 68 & 63,6 & 107 & 49,5 & \\
32 & 29,4 & 77 & 70,6 & 109 & 50,5 & \\
\hline
\end{tabular}

Based on the results of a bivariable analysis using the ChiSquare test showed that all variables of maternal characteristics and child characteristics are not statistically related to variables of psychosocial stimulation that parents do to children. The next analysis is multivariate analysis, which is by selecting the variables to be included in the modeling. Variables that have a $\mathrm{p}$ value $>0.25$ will not be included in this multivariate analysis. Based on the results of the analysis, variables that meet the criteria are the mother's education, mother's occupation, age of the child, and the birth order of the child.

Table 4. Multivariate Analysis Results

\begin{tabular}{|c|c|c|c|c|}
\hline & Variable & Coefficient & $\mathbf{p}$ & $\begin{array}{c}\text { OR }(95 \% \\
\text { CI })\end{array}$ \\
\hline \multirow[t]{4}{*}{$\begin{array}{l}\text { Model } \\
1\end{array}$} & $\begin{array}{l}\text { Mother's } \\
\text { education }\end{array}$ & 0,496 & 0,108 & $\begin{array}{c}1,64 \\
(0,897- \\
3,007)\end{array}$ \\
\hline & $\begin{array}{l}\text { Mother's } \\
\text { job }\end{array}$ & 0,322 & 0,399 & $\begin{array}{c}1,38 \\
(0,653- \\
2,914)\end{array}$ \\
\hline & Child's age & 0,394 & 0,232 & $\begin{array}{c}1,48 \\
(0,777- \\
2,829)\end{array}$ \\
\hline & Birth order & 0,642 & 0,124 & $\begin{array}{c}1,90 \\
(0,838- \\
4,308)\end{array}$ \\
\hline \multirow[t]{3}{*}{$\begin{array}{l}\text { Model } \\
2\end{array}$} & $\begin{array}{l}\text { Mother's } \\
\text { education }\end{array}$ & 0,536 & 0,079 & $\begin{array}{c}1,71 \\
(0,939- \\
3,108)\end{array}$ \\
\hline & Child's age & 0,399 & 0,225 & $\begin{array}{c}1,49 \\
(0,782- \\
2,842)\end{array}$ \\
\hline & Birth order & 0,690 & 0,096 & $\begin{array}{c}1,99 \\
(0,886- \\
4,486)\end{array}$ \\
\hline \multirow[t]{2}{*}{$\begin{array}{l}\text { Model } \\
3\end{array}$} & $\begin{array}{l}\text { Mother's } \\
\text { education }\end{array}$ & 0,525 & 0,084 & $\begin{array}{c}1,69 \\
(0,932- \\
3,066)\end{array}$ \\
\hline & Birth order & 0,709 & 0,085 & $\begin{array}{c}2,03 \\
(0,906- \\
4,558)\end{array}$ \\
\hline
\end{tabular}

Model 1 includes the variables of mother's education, mother's occupation, child age, and childbirth order. Model 2 excludes the work of mothers who have the greatest p-value. The last model showed the variables are associated with psychosocial stimulation are the variables of maternal education and the birth order of children. Although statistically shows an insignificant relationship (p> 0.05), but practically this variable influences psychosocial stimulation. This research was conducted to identify resources and maternal characteristics that influence the care and psychosocial stimulation of children. Psychosocial stimulation is an important issue in the child's growth and development [8].

The results in this study indicate that maternal age is not statistically related to psychosocial stimulation provided to children. The mother's age is divided into reproductive safe age and age at risk. These results are not accordance with research which states that the age of mothers who are too young, ie less than 19 years is associated with an increased risk of premature childbirth and failure of fetal growth, increased risk of infant death, and risk of malnutrition in children [16]. Other research also states that babies born to mothers who are too young are at risk of being born with low body weight. The mechanism of the relationship is still unclear and there are many influential factors. The assumption mentioned is an imbalance between the nutrients needed by the mother and the fetus, especially when the maternal gynecological factor is not yet ripe and is still in its infancy and development. Another opinion states that the mechanism is influenced by socio-economic conditions. Whereas the age of the mother who is too old that is more than 35 years old has almost the same risk as to the mother who is too young. Older mothers have a risk of obesity, diabetes, hypertension, and pregnancy complications [17]. 
Education becomes an important issue in parenting and has an impact on the interaction of parents and children. Adequate education for parents provides important abilities, knowledge, and values that can support and facilitate well in the development and learning process of children. Many studies have been conducted and the results consistently prove that parental education influences many aspects of care and functions in the family, which ultimately relate to the achievement of children's cognitive abilities, emotional social development, and behavior adjustment [18]. The results in this study are not in line with the results of other studies which state that better education and knowledge of mothers can improve the quality of care $[19,20]$. The level of mother's education is significantly related to the involvement of parents in early learning activities at home. Mothers with higher levels of education will be more involved in learning activities and playing with children at home [21]. Maternal education in this study is divided into primary and secondary education categories. The results of the analysis which stated there were no statistical differences between those with primary education and those with secondary education were allegedly due to the relatively small age of the child, so it might be considered not to require much stimulation.

Mother's work is not statistically related to the care and stimulation provided to children. These results are consistent with research conducted by Aji et al [22]. The results of this study are not in line with the results of the study of Salimar, et al who stated that there is a significant relationship between maternal workload and patterns of care for children under five [23]. The results of a qualitative study indicate that working mothers but able to balance work and family and have a husband whose role is to help, then the child will be able to develop optimally. If the mother feels that she can balance work and family, but the husband does not support, then the growth and development of the child are less than optimal [24]. Women who are unemployed or unemployed with low levels of education are associated with poor quality care, which will affect the imbalance in children's lives [25].

Psychological factors of mothers namely depression and anxiety are not statistically related to psychosocial stimulation in this study. These results are not in line with several existing studies. Postnatal depression experienced by mothers tends to negatively influence the parenting process. This condition is caused by symptoms of depression such as deep sadness, withdrawal of the mother from the environment, feeling too sensitive to the environment and a sense of pessimism about the future that dominates the feelings of the mother. The impact is the mother's ability to respond to the environment also decreases. Lovejoy et al [26]. state that not all research results show an association between depression and care, but now there is evidence of the effects of depression on care mediated by socioeconomic factors. Field [27] states that mothers who are depressed will have a disruption in interactions between mother and child. Parenting activities, breastfeeding practices, and children's routines also decrease, as the mother's sensitivity decreases in responding to the child's needs. In a meta-analysis study of mothers who experienced postpartum depression, showed that mothers who were depressed, in the first 3 months of a baby's life or after childbirth, mothers showed more irritability, hostility, less warmth with babies, easier emotions, and more invite a baby to play [26]. The existence of this depression also makes play activities with children will decrease, for example reading books to children, singing together, telling stories, and other play activities [28].

The mechanism of depression in the mother which is a risk factor for the growth and development of the child becomes a complex and complicated problem. Mother's care behaviors and practices are important resource factors in care, for example, feeding care, health care, psychosocial stimulation, and emotional support for the child's needs [29]. Depression experienced by mothers can reduce the ability of mothers to care for their children, so that in the end it can harm the growth and development of children [2,30,31]. Research conducted by Nguyen et al. shows that severe levels of depression are associated with a poor care environment, lack of attachment to children, low utilization of health services, and suboptimal feeding practices as indicated by a low diversity of food consumed by children [32].

Child characteristics including gender, age, and birth order are not statistically related to psychosocial stimulation. This condition is possible because of the perception that the child is still relatively small, so there is not much stimulation that needs to be given to the child. These results are consistent with research which states that the sex of a child is not significantly related to the involvement of parents in early learning activities at home. This indicates that parents of girls have the same play and learning activities as parents of boys [33]. The age of the child has a significant negative relationship with the number of early learning activities provided by parents at home. Parents are more actively involved in the early learning process when children are still infants and under five years old, than if the child has entered kindergarten age. Parents more often play with babies or toddlers and invite to play outside the house or involved in singing and telling stories with babies. Whereas for older children or kindergartens, parents are more likely to read books or look at picture books or counting [33].

\section{CONCLUSION}

Most mothers or caregivers have provided good psychosocial stimulation to children. The characteristics of the mother are not statistically related to the stimulation provided, nor are the characteristics of the child. But the results of multivariate analysis, maternal education, and birth order may contribute to the psychosocial stimulation provided to children. 


\section{RECOMMENDATION}

The risk for the low quality of care stimulation is related to formal maternal education, so programs that informally enhanced the quality of stimulation among low-educated mothers need to be strengthened. The significant prevalence of psychological problems in mothers needs to be followed up by looking at their effects on the child's growth and development outcomes.

\section{REFERENCES}

[1] Grantham-McGregor S, Cheung YB, Cueto S, Glewwe P, Richter L, Strupp B. Developmental Potential in the First 5 Years for Children in Developing Countries. Lancet. 2007;369(9555):60-70.

[2] Walker SP, Wachs TD, Meeks Gardner J, Lozoff B, Wasserman GA, Pollitt E, et al. Child Development: Risk Factors for Adverse Outcomes in Developing Countries. Lancet. 2007;369(9556):145-57.

[3] Britto PR, Lye SJ, Proulx K, Yousafzai AK, Matthews SG, Vaivada T, et al. Nurturing Care: Promoting Early Childhood Development. Lancet. 2017;389(10064):91-102.

[4] Biedinger N. The Influence of Education and Home Environment on the Cognitive Outcomes of Preschool Children in Germany. Child Dev Res. 2011;2011:1-10.

[5] Young ME, Richardson LM. Early Child Development from Measurement to Action. Measurement. Washington DC: The World Bank; 2007.

[6] Martin C, Colbert K. Parenting: A Life Span Perspective. New York: McGraw-Hill; 1997.

[7] Brooks J. The Process of Parenting. Ninth Edit. Vol. 3. New York: Mc Graw Hill; 2011.

[8] World Health Organization. The Importance of Caregiver-Child Interactions for the Survival and Healthy Development of Young Children. 2004.

[9] Vasilyeva EN, Shcherbakov A V. Parental Roles and Types of Parentings as Determinants of a Preschooler's Emotional and Personal Well-being. Procedia - Soc Behav Sci. 2016;233(2016):144-9.

[10] Thomson P, Jaque S. Attachment, Parenting, and Childhood Adversity. In 2017. p. 167-86.

[11] Kennedy G, Nantell G, Shetty P. The Scourage of Hidden Hunger: Global Dimensions of Micronutrient Deficiencies. Swiss; 2003.

[12] Bradley R, Corwyn R. Sosioeconomic Status and Child Development. Annu Rev Psychol. 2002;53:371-99.

[13] Huda SN, Grantham-McGregor SM, Rahman KM, Tomkins A. Biochemical Hypothyroidism Secondary to Iodine Deficiency is Associated with Poor School Achievement and Cognition in Bangladeshi Children. J Nutr. 1999;129(5):980-7.

[14] Engle PL, Black MM, Behrman JR, Cabral de Mello M, Gertler PJ, Kapiriri L, et al. Strategies to Avoid the Loss of Developmental Potential in more than 200 Million Children in the Developing World. Lancet. 2007;369:22942 .
[15] Latifah L, Nurcahyani YD, Yunitawati D, Kusrini I, Mulyantoro DK. Breastfeeding Iodine Level and Infant Development in Replete and Non Replete Iodine Area. In: Asian Congress of Nutrition. Denpasar; 2019.

[16] Lawlor DA, Mortensen L, Andersen AMN. Mechanisms Underlying the Associations of Maternal Age with Adverse Perinatal Outcomes: A Sibling Study of 264 695 Danish Women and Their Firstborn Offspring. Int J Epidemiol. 2011;40(5):1205-14.

[17] Fall CHD, Sachdev HS, Osmond C, RestrepoMendez MC, Victora C, Martorell R, et al. Association between Maternal Age at Childbirth and Child and Adult Outcomes in the Offspring: A Prospective Study in Five Low-Income and Middle-Income Countries (COHORTS Collaboration). Lancet Glob Heal. 2015;3(7):e366-77.

[18] Duckworth K, Sabates R. Effects of Mothers' Education on Parenting: an Investigation Across Three Generations. London Rev Educ. 2005;3(3):239-64.

[19] Yulita R. Hubungan Pola Asuh Orang Tua terhadap Perkembangan Anak Balita di Posyandu Sakura Ciputat Timur. UNiversitas Islam Negeri Syarif Hidayatullah; 2014.

[20] Hastuti D, Alfiasari A, Chandriyani C. Nilai Anak, Stimulasi Psikososial, dan Perkembangan Kognitif Anak Usia 2-5 Tahun pada Keluarga Rawan Pangan di Kabupaten Banjarnegara, Jawa Tengah. J Ilmu Kel dan Konsum. 2010;3(1):27-34.

[21] Proulx K. Study of Parental Knowledge, Attitudes and Practices Related to Early Childhood Development. Solomon Islands; 2014.

[22] Aji DSK, Wati EK, Rahardjo S. Analisis Faktorfaktor yang Berpengaruh terhadap Pola Asuh Ibu Balita di Kabupaten Banyumas. J Kesmas Indones. 2016;8(1):1-15.

[23] Salimar, Hastuti D, Latifah M. Hubungan Beban Kerja, Pengetahuan Ibu, dan Pola Asuh Psikososial Dengan Perkembangan Kognitif Anak Usia 2-5 Tahun pada Keluarga Miskin. PGM. 2011;34(1):39-49.

[24] Handayani A, Munawar M. Work Family Balanced and Quality of Parenting in Optimizing Children Development. Indones J Early Child Educ Stud. 2015;4(1):11-8.

[25] Augustine JM. Mothers' Employment, Education, and Parenting. Work Occup. 2014;41(2):237-70.

[26] Lovejoy MC, Graczyk PA, O’Hare E, Neuman G. Maternal Depression and Parenting Behavior: A MetaAnalytic Review. Clin Psychol Rev. 2000;20(5):561-92.

[27] Field T. Postpartum Depression Effects on Early Interactions, Parenting, and Safety Practices: A Review. Infant Behav Dev. 2010;33(1):1-9.

[28] Paulson JF, Dauber S, Leiferman JA. Individual and Combined Effects of Postpartum Depression in Mothers and Fathers on Parenting Behavior. Pediatrics. 2006;118(2):659-68.

[29] Engle PL, Menon P, Haddad L. Care and Nutrition: Concepts and Measurement. Washington DC: Food Consumption anad Nutrition Division International Food Policy Research Institute; 1999. 
Associated with Child Growth and Development: Evidence

[30] Rahman A, Patel V, Maselko J, Kirkwood B. The Neglected " $m$ " in MCH Programmes - Why Mental Health of Mothers is Important for Child Nutrition. Trop Med Int Heal. 2008;13(4):579-83.

[31] Stewart RC. Maternal Depression and Infant Growth A Review of Recent Evidence. Matern Child Nutr. 2007;3(2):94-107.

[32] Nguyen PH, Friedman J, Kak M, Menon P, Alderman

H. Maternal Depressive Symptoms are Negatively from Rural India. Matern Child Nutr. 2018;14(4):1-9.

[33] Alderman H. No Small Matter The Impact of Poverty, Shocks, and Human Capital Investments in Early Childhood Development. Alderman H, editor. Washington DC: The World Bank; 2011. 